\title{
Gübre üreticisinin hedef pazar seçiminde bütünleşik AHP-TOPSIS yöntemi
}

\section{Integrated AHP-TOPSIS method for fertilizer producer's target market selection}

\author{
Zeynep ÜNAL ${ }^{1}$ (i), Emre İPEKÇİ ÇETİN ${ }^{2}$ (i) \\ ${ }^{1}$ Akdeniz Üniversitesi, Sosyal Bilimler Enstitüsü, Ekonometri A.B.D., Antalya \\ ${ }^{2}$ Akdeniz Üniversitesi, İktisadi ve İdari Bilimler Fakültesi, Ekonometri Bölümü, Antalya \\ Sorumlu yazar (Corresponding author): E. İpekçi Çetin, e-posta (e-mail): ecetin@akdeniz.edu.tr \\ Yazar(lar) e-posta (Author e-mail): zeynepunal1010@hotmail.com
}

\section{MAKALE BİLGISI}

Alınış tarihi 28 Haziran 2019

Düzeltilme tarihi 19 Eylül 2019

Kabul tarihi 24 Eylül 2019

\section{Anahtar Kelimeler:}

AHP

TOPSIS

Hedef pazar

Gübre üreticisi

\begin{abstract}
ÖZ
Bir işletmenin uluslararası ticarette başarılı olabilmesi ihracat pazar araştırması sürecinin verimliliğiyle ilişkilidir. Genellikle uluslararası piyasalarda bulunan tüm firsatlar tek seferde kullanılamadığı için hedef pazarlar seçerek o pazarlara odaklanmak gerekmektedir. Literatürde uluslararası pazar yeri seçimi için farklı yöntemler ve modeller önerilmektedir. Her işletme seçilen modeli belirli bir durum için ve kendi yapısı için uyarlamalıdır. Bu çalışmada Antalya'da faaliyet gösteren bir gübre üreticisi işletmesinin hedef pazar seçimi problemi üzerinde durulmuştur. Çalışmada öncelikle AHP Yöntemi kullanılarak işletmenin hedef pazar seçiminde önem verdiği kriterlerin ağırlıkları belirlenmiştir. Nüfus, kişi başı GSMH, gübre tüketimi, gübre üretimi, gübre ticareti dengesi, iş yapma kolaylı̆̆ı, ülkelere uzaklık ve lojistik performans şeklinde belirlenen kriterler içerisinde en önemli ilk iki kriterin ülkelere uzaklık ve ticaret dengesi olduğu tespit edilmiştir. AHP yöntemiyle elde edilen kriter ağırlıkları TOPSIS yönteminde kriterlerin ağırlıkları olarak kullanılmış ve 33 ülke arasından hedef pazar için uygun ilk 10 ülke belirlenmişsir. Ele alınan kriterler açısından hedef pazar olarak Hindistan ve Brezilya'nın en uygun ilk iki ülke olduğu ortaya çıkmıștır.
\end{abstract}

\section{ARTICLE INFO}

Received 28 June 2019

Received in revised form 19 September 2019 Accepted 24 September 2019

\section{Keywords:}

AHP

TOPSIS

Target market

Fertilizer producer

\begin{abstract}
The efficiency of a company in international trade is related to the efficiency of the export market research process. Generally, since all opportunities in international markets cannot be used in one time, it is necessary to focus on those markets by selecting target markets. In the literature, different methods and models have been proposed for the selection of international market place. Each company must adapt the selected model to a specific situation and its structure. In this study, the target market selection problem of a fertilizer manufacturer operating in Antalya is emphasized. In the study, first of all, using AHP method, weights of the criteria (population, per capita GNP, fertilizer consumption, fertilizer production, fertilizer trade balance, ease of doing business, distance to countries and logistic performance) that the enterprise attaches importance to the selection of target market were determined. Distance to countries and trade balance are the two most important criteria among these criteria. Determined criteria were weighted by Analytical Hierarchy Process (AHP) and it was determined that the first two criteria were distance and trade balance to countries. The benchmark weights obtained by the AHP method were used as criterion weights in TOPSIS method and the top 10 countries were selected among 33 countries for the target market. In terms of the criteria considered, India and Brazil are the most suitable first two countries as the target market.
\end{abstract}

\section{Giriş}

Hedef pazar seçimi işletmenin başarısını ve geleceğe yönelik tüm faaliyetlerini önemli derecede etkilemektedir. Yurtdışı faaliyetleri için hedef pazarın belirlenmesi kararı genelde ihracatçı şirketlerin yöneticileri tarafindan tecrübelerine ve içgüdülerine dayalı olarak gerçekleşmekte, kullanılan kriterler firmadan firmaya değişmektedir (Holzmüller ve Kasper 1990). Şirketlerin başarısını etkileyecek önemli kararları şirket yöneticilerinin inisiyatifine bırakmak yerine diş ticaret verilerinden ve bilimsel yöntemlerden yararlanarak sistematik yaklaşımla vermek mümkündür (Gould 2002). Literatürde hedef pazar araştırmaları yapılırken pazarın genel durumu ve pazarın çekiciliği değerlendirilmektedir. Hedef pazar araştırmasında pazar büyüklügü, son yıllardaki pazar büyümesi, rekabet imkânı, ilgili ürünlerin talep oranları, ilgili ülkenin ithalat 
miktarları gibi kriterler kullanılarak alternatif pazarlar analiz edilmelidir. Nüfus, GSYİH, enerji tüketimi, enflasyon gibi bazı parametreler pazar büyüklüğünü doğrudan ölçmese de oluşabilecek firsatları göz önüne sermektedir (Sakarya ve ark. 2007). Hedef pazar seçiminde etkili kriterler sektörden sektöre hatta işletmeden işletmeye farklılık gösterebilir. Hedef pazar seçimi ve etkili olan kriterler ile ilgili literatürde yer alan çalışmalardan bazıları aşağıdaki kısımda özetlenmektedir.

Simkin ve Dibb (1998) hedef pazarlara öncelik atamak için kullanılabilecek kriterleri belirlemek amaciyla önde gelen 150 şirketin pazarlama yöneticilerinden anket yoluyla bilgi almıştır. $\mathrm{Bu}$ anketin sonuçlarına göre kârlılık, pazar payı ve pazarın büyüklüğü kriterleri ön plana çıkmıştır. Çalışmada aynı zamanda basit yaklaşım, hızlı ve etkili yaklaşım, uzun vadeli yaklaşım ve analitik yaklaşımlar gibi farklı hedef pazar belirleme stratejilerine de değinilmiştir. Analitik yaklaşımda pazar büyüklüğü, pazar payı, iş yapma avantajları, rekabet yoğunluğu, pazar büyümesi, uzun vadeli ilişkiler ve müşteri kalitesinin etkili olduğu gösterilmiştir. Robertson ve Wood (2001) hedef pazar seçiminde kullanılmak üzere toplam 200 kriter içerisinden 60 kriter belirleyerek 6 boyutla ifade etmişlerdir. Dış ticaret uzmanları ile yapılan görüşmeler sonunda kriterler önem sırasına göre pazarlama potansiyeli, kanuni yükümlülükler, politik şartlar, altyapı, ekonomik şartlar, kültürel uzaklık olarak belirlenmiştir. Rahman (2003) hedef pazar seçiminde önerilen modelin kapsamlı olmasının yanında basit olması gerektiğini savunmuştur. Bu nedenle hedef pazar seçiminde iki aşamalı model önermiştir. Birinci aşamada makro ve mikro ekonomik göstergeler dikkate alınarak pazarların çekiciliği değerlendirilmektedir. İkinci aşamada ise maliyetler, yapısal uygunluk, hükümet politikaları ve firmaya özgü kriterler değerlendirilerek karar verilmektedir. Çalışmada eğitim, elektronik, paketlenmiş gida, araba endüstrisi gibi farklı sektörden on iki örnek üzerinde uygulama yapılmıştır. Makro ekonomik kriterler arasında GSMH, GSMH büyüme oran1, enflasyon oranı, nüfus, orta gelirli nüfus payı, okuryazarlık oran1, para rezervi, döviz kurunun istikrarı gibi kriterlerin yer aldığ ekonomik göstergelerin eklenmesi önerilmiştir. Örneğin gida sektöründe faaliyet gösteren firmalar için yaşa göre nüfus dağılımı, kişi başı gıda tüketim miktarları, gıda için harcanan gelir oranı, yeme içme alışkanlıkları gibi faktörlerin ilave edilmesinin modele katkı sağlayacağı açıklanmıştır. İkinci aşamada ise dağıtım maliyetleri, pazar araştırma ve seyahat maliyetleri, komisyon maliyetleri, danışman ve pazarlama maliyetleri, özel ambalaj maliyetleri, ürün değişikliği maliyetleri dikkate alınarak birinci aşamada belirlenen liste tekrar incelenmiștir. Belirlenen ülkelerde kanuni düzenlemelerin de mutlaka incelenmesi gerektiği belirtilmiş ve firmaların kendine özgü kriterler açısından incelenip nihai kararın verilmesi gerektiği belirtilmiştir. Sakarya ve ark. (2006) literatürde yaygın olarak önerilen makroekonomik ve politik kriterlerin kullanılması durumunda gelişmekte olan pazarların gözden kaçmasına sebep olunabileceğini belirtmiştir. $\mathrm{Bu}$ nedenle gelişen pazarlara şans tanıyacak kriterlere ihtiyaç duyulduğu vurgulanmıştır. Çalışmada gelecekteki güçlü pazar potansiyeli, yönetilebilir kültürel mesafe seviyesi, destekleyici ve gelişmekte olan yerel sanayi ve yabancı ürünlere karşı olumlu müşteri memnuniyeti gibi faktörlerin dikkate alınması önerilmiştir. Malhotra ve ark. (2009) ülkeler arasındaki farklı uzaklık şekillerini inceleyerek hedef pazar seçimini en çok etkileyen faktörleri tespit etmişlerdir. Kültürel ve coğrafi uzaklığın ihracat oranına negatif etki ederken yönetimsel ve ekonomik uzaklığın pozitif etki ettiği gösterilmiştir. Bu çalışma sektörler arasındaki farklılıklar gözetilmeksizin yapılmıştır. Herhangi bir sektör için hedef pazar belirlerken sektöre özel kriterlerin ilave edilmesi gerektiği vurgulanmıştır. Steenkamp ve ark. (2009) Güney Afrika için Cuyvers (1995) karar destek modelini uygulayarak 12695 ürün- ülke kombinasyonları arasından ihracat firsatlarını tespit etmiştir. Kullanılan karar destek modeli dört filtrenin kullanımıyla ihracat potansiyeli daha düşük olan ülkeleri ortadan kaldıran ardışık bir filtreleme sürecinden oluşmaktadır. İlk filtre, kişi başına GSYİH ve kişi başına GSYİH büyümesi gibi ülkelerin makro ekonomik ortamını göz önüne alarak ülke risk derecelemesi yapmakta ve riskli olanları filtrelemektedir. İkinci filtrede, kisa ve uzun vadeli ithalat pazarındaki büyüme ve göreceli pazar büyüklüğ̈ dikkate alınarak filtreleme yapılmaktadır. Üçüncü filtrede, Herfindahl-Hirschmann Endeksi, ithalatçı ülkelerin pazar yoğunlaşmasının ve giriş engellerinin bir göstergesi ile tekrar filtrelenmektedir. Dördüncü filtrede ise önceki filtrelerde tespit edilen ülkeler ihracat firsatları açısından sınıflandırılmaktadır. Górecka ve Szałucka (2013) firmaların uluslararası pazara açılmasında makroekonomik, sosyal ve politik, ürün talebi, maliyet faktörlerinin etkili olduğunu vurguladıkları çalışmalarında bir firmanın hedef pazar kararları için EXPROM II, PROMETHE II, ELECTRE III gibi çok kriterli karar verme tekniklerinden yararlanmışlardır. Górecka ve Szałucka (2013), çalışmalarında pazar büyüklüğü, pazar büyümesi, ekonomik kalkınma, yaşam kalitesi, altyapı, pazar yoğunluğu, pazar algılama, kültürel uzaklık, üretim faktörleri ve yatırım ortamı gibi kriterleri kullanmışlardır. Miečinskienè ve ark. (2014) bir şirketin hedef pazar seçiminde, nüfus artış hızı, işsizlik seviyesi, enflasyon, GSYIHH büyüme oranı, kişi başına düşen GSYIH, kişi başına düşen ihracat ve kişi başına düşen ithalat gibi değişkenler kullanmıştır. Hedef pazar seçimi için istatistiksel veri analizi ve uzman değerleme yöntemi kullanılan bu çalışmada analiz edilen şirketin ürün ihraç edebileceği ülkeler tespit edilmiştir. Şener (2014) çeşitli ülkelere ihracat yapan bir Türk seramik şirketinin pazar geliştirme stratejisi kapsamında hem sayısal hem de sayısal olmayan ölçütler kullanarak alternatifler arasından en uygun olanını seçmiştir. Çalışmada; operasyon imkanları, hedef pazarın iletişim altyapısı, ekonomik büyüme oranı, diğer pazarlara yakınlık, hedef pazardaki rekabet avantajı, talep, yasal sistemin işleyişi ve ticaret anlaşmaları olmak üzere toplam sekiz kriter kullanılmıştır. AHP tekniğine uygun olarak ikili karşılaştırmalar yapıldıktan sonra kriterlerin göreceli önem değerleri ve işletmenin yeni yatırım yapması için en uygun yer belirlenmiştir.

Toksarı ve Toksarı (2011) çalışmalarında hedef pazarın belirlenmesinde hedef pazar stratejilerini değerlendirerek bütün durumlar için en iyi alternatifi seçmişlerdir. Stratejilerin üstünlüklerinin belirlenmesinde bulanık AHP tekniği kullanılarak beyaz eşya sektörü için pazar seçimi uygulaması yapılmıştır.

Söyler ve Yaraş (2016) küresel pazara girmenin riskinin değerlendirilmesinde bulanık AHP ve ülkelerin bu risk ölçüsüne göre sıralanmasında bulanık TOPSIS yöntemini kullanmıştır. Uzman kişilerin görüşlerine başvurularak, pazara giriş kararında önemli etkenlerin göreceli önem düzeyleri belirlenmiştir. Bu önem dereceleri göz önüne alınarak bulanık AHP ile etkenlerin ağırlıkları belirlenmiştir. Yavuz (2016) çalışmasında, pazar seçimi konusunda alternatiflerin değerlendirilmesinde kullanılan kriterlerin belirlenmesinde Delphi metodundan faydalanmıştır. Kriter ağırlıklarının hesaplanması için Entropi ağıllık ve uzman görüşlerinin dikkate alındığı bulanık ağırlık hesaplamaları kullanılmış ve iki farklı senaryo şeklinde PROMETHEE yönteminde kullanmıştır. Hatay'daki mobilya sektörünün 
Türkiye genelinde pazar seçimi problemine uygulanan iki senaryoda elde edilen sıralamalar birbirine yakın sonuçlar elde etmiştir.

Yılmaz ve ark. (2017) çalışmalarında, pazar seçimindeki etkenlerin ağırlıklarının tespiti için Analitik Hiyerarşi Prosesi (AHP) ve en iyi alternatifin sıralanması VIKOR yöntemini bir arada kullanarak mobilya sektörü için hedef pazar seçimine yönelik uygulama yapmıştır.

$\mathrm{Bu}$ çalışmada Antalya'da gübre üretimi ve pazarlaması yapan bir işletmenin hedef pazar seçimi problemine çok kriterli karar verme yöntemleri ile çözüm aranması amaçlanmaktadır. İşletme tarafindan ve literatürden yararlanılarak belirlenen kriterler AHP yöntemiyle değerlendirilerek önem dereceleri belirlenmiş ardından TOPSIS yöntemine göre alternatif ülkeler bu kriterler dikkate alınarak sıralanmıştır. Böylece ilgili işletme için en uygun hedef pazar yeri seçimi yapılmıştır.

\section{Materyal ve Yöntem}

Literatürde hedef pazar seçiminde hangi kriterlerin kullanılması gerektiği ve nasıl ölçülmesi gerektiği üzerine bir uzlaşı bulunmamaktadır. Genellikle önerilen kriterler arasından hangi kriterlerin en uygun olacağına karar vermek için mevcut durumu değerlendirecek uzman görüşüne ihtiyaç duyulmaktadır. Kriterler belirlenirken işletmenin doğrudan uluslararası genişlemesinin hedefleri dikkate alınarak tam olarak hangi yönde ilerleme kaydetmek istediği net olarak anlaşılmalıdır (Górecka ve Szałucka 2013).

Bu çalışmada ilk olarak ele alınan işletme için hedef pazar seçiminde etkili olabilecek kriterlerin belirlenmesi amaçlanmıştır. $\mathrm{Bu}$ amaçla pazar seçimi konusunda tecrübesi olan firma yöneticilerinden genel müdür, ihracat müdürü, operasyon müdürü, dış ticaret danışmanı ve finans müdürü ile toplantı ortamında hedef pazar seçiminde literatürde s1k kullanılan kriterler incelenmiş ve işletme için en önemli olduğu düşünülen kriterler değerlendirilmiştir. Bu kriterler nüfus, kişi başı GSMH, gübre tüketimi, gübre üretimi, gübre ticareti dengesi, iş yapma kolaylığı, ülkelere uzaklık ve lojistik performans şeklinde belirlenmiştir. Daha sonra Ticarert Bakanlığı tarafindan yayınlanan 2016-2017 Hedef Pazar ülke listesinde yer alan 15 ülke ve öncelikli pazar listesinde yer alan 33 ülke alternatif olarak belirlenmiştir (Ticaret Bakanlığı 2015). Firmanın yurtdışı tanıtım faaliyetleri için sadece 10 ülke için ayrılmış bütçesi olduğundan bu bütçeyi verimli kullanabilmesi adına en öncelikli pazarların belirlenmesi gerekmektedir. Firma yöneticileri tarafindan belirlenen kriterlerin açıklamaları aşağıda k1saca özetlenmektedir.

Nüfus: Birçok çalışmada ülkelerin nüfusu önemli bir değişken olarak yer almaktadır. Bu çalışmada ele alınan gübre sektörü için hedef pazar seçiminde de işletme yöneticileri ülke nüfusunun önemli olduğunu vurgulamışlardır. Nüfus verisi olarak Dünya Bankası veri tabanında bulunan 2015 yılına ait veri seti kullanılmıştır. Veri tabanında yer alan veri seti o ülkede ikamet eden kişilerin vatandaşlık durumuna bakılmaksızın oluşturulmuştur (World Bank Group 2015).

Kişi başı GSMH: Hedef pazar belirlemede pazarda satışın başarılı ve kârlı olabilmesi açısından ülkenin ekonomik durumunun da göz önüne alınması gerekmektedir. Bunu belirleyecek birçok kriter bulunmakla beraber literatürde en yaygın kullanılan kriterlerden birinin kişi başı GSMH olduğu görülmektedir (Miečinskienè ve ark. 2014). Veri setindeki kişi başı GSMH değerleri ilgili ülkenin 2015 yılına ait GSMH değerinin 2015 y1lı nüfusuna bölünerek elde edilmiştir (World Bank Group 2015).

Gübre tüketimi: Birleşmiş Milletler Tarım ve Gıda Teşkilatı (FAO) tarafindan tarıma elverişli toplam alan, ekip biçme faaliyetleri için ayrılmış arazi olarak tanımlanmaktadır. Veri setindeki tarıma elverişli toplam alan mera, çayır, tarla, bahçe, nadas için ayrılmış tüm alanı hektar bazında içermektedir. Hektar başına gübre tüketimi kriteri tarıma elverişli alanda hektar başına kaç kilo gübre kullanıldığının bilgisini vermektedir. Buradaki gübre çeşitleri ögütülmüş kaya fosfat dahil tüm fosfatlı, azotlu, potas gübreleri kapsamaktadır (World Bank Group 2015). Analiz yapılan işletme yöneticileri tarafından alternatif ülkede gübre talebi hakkında fikir vermesi amacıyla Dünya Bankası veri tabanında 2013 yılına ait olan tarıma elverişli toplam alan ile hektar başına gübre tüketimi çarpım değerinin kullanılması önerilmiştir.

Gübre üretimi: İlgili ülkedeki talebi belirlemek için gübre tüketimi kadar gübre üretimi de önemlidir. Yüksek gübre tüketen bazı ülkelerde gübre üretimi yapılarak ihtiyaç karşılandığ için dışarıdan gübre tedarik edilmemektedir. Analiz yapılan firma yöneticileri tarafindan alternatif ülkede gübre talebi hakkında fikir vermesi amacıyla Dünya Bankası veri tabanında 2013 yılına ait olan gübre üretimine oranla gübre tüketimi verileri kullanılması önerilmiştir.

Gübre ticareti dengesi: Bir ürünün alternatif ülkeye ihracat firsatı araştırılırken ilgili ülkenin ithalat istatistikleri anlamlı bilgi vermektedir. Fakat gübre spesifik bir üründür. Bazı ülkeler bir gübre çeşidini ithal ederek daha yüksek değerli gübre üretip ihraç etmektedir. Dolayısıyla seçilen ülkenin gübre ihracatı ile gübre ithalatı arasındaki ticari dengenin bu analizde önemli bir kriter olduğu düşünülmektedir. Gübre sektöründe 2015 yılına ait ithalat verilerinden ihracat verileri çıkarılarak gübre ticareti dengesi ile ilgili veriler oluşturulmuştur (Trademap 2015).

İş yapma kolaylığı: Bir ülke ile ticari ilişkilerin olumlu gelişmesinde o ülkede iş yapma kolaylığı önemli bir ölçüttür. Dünya Bankası veri tabanında ülkeler iş yapma kolaylığ açısından büyükten küçüğe sıralanmıştır. Yani birinci sırada olan ülke en kolay iş yapılan ülkedir. İş yapma kolaylığ 10 maddelik bir ölçek kullanılarak ve maddelerin ortalamaları alınarak oluşturulmuştur (World Bank Group 2015).

Ülkelere uzaklık: Seçilen hedef ülkenin mesafe olarak yakınlığı hem giderleri hem operasyonu önemli ölçüde etkilediği için analiz yapılan firma yöneticileri tarafından alternatif ülkelere uzaklık kriteri eklenmesi önerilmiştir. TOPSIS yönteminde kullanılmak üzere en uzak ülkenin mesafesi diğer ülkelere olan uzaklık değerlerinden çıkarılmıştır. Böylece en uzak ülke 0 değerini alırken, en yakın ülke ise en yüksek tercih edilebilir ülke konumuna gelmiştir. Uzaklıkların hesabında Distance From To (2015) kaynağından faydalanılmıştır.

Lojistik performans: Dünya Bankası tarafindan Logistic Performance Index olarak yayınlanan ve online olarak veritabanından erişilebilen indeks kullanılmıştır. Lojistik Performans Endeksi, ülkelerin ticaret lojistiği konusundaki performanslarını iyileştirmek için neler yapabileceklerini belirlemelerine yardımcı olmak için oluşturulmuş etkileşimli bir kıyaslama aracıdır. LPI, uluslararası operatörlerin faaliyet gösterdikleri ülkeler hakkında geri bildirimlerini içeren anketlere dayanmaktadır. Operatörlerden gelen geri bildirimler, lojistik zincirinin kilit bileşenlerinin performansına ilişkin nicel verilerle desteklenmektedir. Bu nedenle, LPI hem kalitatif hem de kantitatif unsurlardan meydana gelerek bu ülkeler için 
lojistik dostu profiller oluşturmaya yardımcı olmaktadır. Her ülkeye 5 (en iyi) ile 1 (kötü) olacak şekilde puan verilmiştir (World Bank Group 2015).

\subsection{Analitik hiyerarşi yöntemi (AHP)}

Analitik Hiyerarşi Yöntemi (AHP), tercihler veya alternatiflerin göreceli karşılaştırmalarının yapılandırılması ve değerlendirilmesi ile yöneticilerin daha etkili kararlar vermesine yardımcı olmak için geliştirilmiş bir yöntemdir. Basit ve kullanışlı olması sebebiyle yöneticiler ve araştırmacılar tarafindan benimsenmektedir. Temel olarak AHP karmaşıklığa sistemsel yaklaşmakta, ölçümlerde ve dereceleme işlemlerinde karar vericiye yardımcı olmakta ve birçok alanda yaygın olarak kullanılmaktadır. Bunun yanında sonuçları beklentiler ve yönetici algısı doğrultusunda oluşturması yöntemin en büyük artılarındandır (Bhushan ve Rai 2007). Yöntemin adımları aşağıdaki şekilde özetlenebilir (Soner ve Önüt 2006):

Adım 1: $\mathrm{Bu}$ adımda ikili karşılaştırmaların yapılacağı karşılaştırma matrisi oluşturulmaktadır. Bu matris $n x n$ boyutlu kare bir matristir.

$$
A=\left[\begin{array}{cccc}
a_{11} & a_{12} & \ldots & a_{1 n} \\
a_{21} & a_{22} & \ldots & a_{2 n} \\
\vdots & \vdots & \vdots & \vdots \\
a_{n 1} & a_{n 2} & \ldots & a_{n n}
\end{array}\right]
$$

Köşegen üzerindeki değerler bir kriterin kendisi ile karşılaştırmasını gösterdiğinden 1 değerini alır. Kriterlerin ikili karşılaştırması yapılırken Çizelge 1'de verilen Saaty tarafından oluşturulmuş 1-9 ölçeğinin kullanılması önerilmektedir.

Çizelge 1. AHP İkili Karşılaştırma Skalası (Saaty'nin 1-9 ölçeği) (Saaty ve Vargas 2001).

Table 1. AHP Pairwise Comparison Scale (Saaty's 1-9 Scale) (Saaty ve Vargas 2001).

\begin{tabular}{cll}
\hline $\begin{array}{c}\text { Önem } \\
\text { Derecesi }\end{array}$ & \multicolumn{1}{c}{ Tanım } & \multicolumn{1}{c}{ Açıklama } \\
\hline 1 & Eşit önemli & $\begin{array}{l}\text { İki faaliyet de eşit düzeyde } \\
\text { amaca katkı sağlamaktadır. } \\
\text { Deneyim ve yargı bir faaliyeti } \\
\text { diğerine kısmen tercih } \\
\text { etmektedir. }\end{array}$ \\
3 & $\begin{array}{l}\text { Biri diğerine göre } \\
\text { çok az önemli }\end{array}$ & $\begin{array}{l}\text { Deneyim ve yargı bir faaliyeti } \\
\text { diğerine daha çok tercih } \\
\text { etmektedir. }\end{array}$ \\
5 & $\begin{array}{l}\text { Kunvetli derece } \\
\text { önemli }\end{array}$ & $\begin{array}{l}\text { Bir faaliyet diğerine göre üstün } \\
\text { ve baskınlığı uygulamada } \\
\text { rahatlıkla görülmektedir. } \\
\text { Bir faaliyetin diğerinden } \\
\text { üstünlüğü kanıtlanmış ve faaliyet } \\
\text { en yüksek kabul seviyesindedir. } \\
\text { Önem dereceleri hakkında tam } \\
\text { karar verilememe durumu }\end{array}$ \\
\hline 9 & $\begin{array}{l}\text { Aşırı derecede } \\
\text { önemli }\end{array}$ & Ara değerler
\end{tabular}

Adım 2: Adım 1'de oluşturulan karşılaştırma matrisi bu adımda normalize edilmektedir. Normalizasyon işlemi için sütun toplamları alındıktan sonra her değer kendi sütun toplamına bölünmektedir.

$$
b_{i j}=\frac{a_{i j}}{\sum_{i=1}^{n} a_{i j}}
$$

Adım 3: Bu adımda normalize edilen karar matrisinde satır ortalamaları (aritmetik ortalama) alınarak ağırlıkların oluşması sağlanmaktadır.

$$
w_{i}=\frac{\sum_{j=1}^{n} b_{i j}}{n}
$$

Adım 4: Ağırlıklar elde edildikten sonra karşılaştırma matrisinin tutarlık hesabının yapılması gerekmektedir. Tutarlılık hesaplaması için ise öncelikle tutarlılığa yakınlık göstergesi olarak nitelendirilen "tutarlılık indeksi (CI)" elde edilmektedir. Tutarlılık indeksinin hesaplanmasında $\mathrm{CI}=\left(\lambda_{\max }-\mathrm{n}\right) /(\mathrm{n}-1)$ eşitliği kullanılmaktadır.

Hesaplanan CI değeri kullanılarak "tutarlılık oranı $\mathrm{CR}=\mathrm{CI} / \mathrm{RI}$ " elde edilmektedir. Buradaki RI değeri Ortalama Rassal Tutarlılık olarak ifade edilmekte olup, değerleri Çizelge 2'de verilmiştir.

Çizelge 2. Ortalama Rassal Tutarlılık İndeksi (Vargas ve Saaty 1982).

Table 2. Avarage random index of consistency (Vargas ve Saaty 1982).

\begin{tabular}{ccccccccccc}
\hline $\mathbf{N}$ & $\mathbf{1}$ & $\mathbf{2}$ & $\mathbf{3}$ & $\mathbf{4}$ & $\mathbf{5}$ & $\mathbf{6}$ & $\mathbf{7}$ & $\mathbf{8}$ & $\mathbf{9}$ & $\mathbf{1 0}$ \\
\hline $\mathbf{R I}$ & 0 & 0 & 0.58 & 0.9 & 1.12 & 1.24 & 1.32 & 1.41 & 1.45 & 1.49
\end{tabular}

AHP'de tutarlılık oranının 0.10 değerinden küçük çıkması beklenmektedir. Bulunan bu değer 0.10 'dan büyük ise ikili karşılaştırma matrisi karar verici tarafından yeniden oluşturulmalıdır. Oluşturulan karar matrisi ile yukarıdaki adımların tekrar edilmesi ve istenen seviyede tutarlılık oranına sahip bir matris ile devam edilmesi gerekmektedir (Özyörük ve Özcan 2005).

\subsection{TOPSIS yöntemi}

TOPSIS (Technique for Order Preference by Similarity to Ideal Solution) yöntemi seçilen alternatifin ideal çözüme göre en kısa mesafede, istenmeyen çözüme göre ise en uzak mesafede olması gerektiği yaklaşımına göre geliştirilmiştir (Hwang ve Yoon 1981). TOPSIS yöntemi rasyonel ve kolay kavranabilir olmasından dolayı çok ilgi görmüştür, ayrıca hesaplamadaki basitliği ve değerlendirme kriterlerinin ağırlıklandırılmasına imkan vermesi nedeniyle bir çok alanda uygulanmıştır (Çakır ve Perçin 2013).

TOPSIS yönteminde kullanılan karar matrisinin satırlarında sıralanmak istenen $\mathrm{m}$ tane alternatif, sütunlarında ise değerlendirmede kullanılacak $\mathrm{n}$ tane kriter yer almakta olup başlangıç matrisi olarak tanımlanmaktadır. Başlangıç matrisi aşağıdaki gibi gösterilmektedir (Uygurtürk ve Korkmaz 2012):

$$
\left[\begin{array}{cccccc}
x_{11} & x_{12} & \cdot & x_{1 j} & \cdot & x_{1 n} \\
x_{21} & x_{22} & \cdot & x_{2 j} & \cdot & x_{2 n} \\
\cdot & \cdot & \cdot & \cdot & \cdot & \cdot \\
x_{i 1} & x_{i 2} & \cdot & x_{i j} & \cdot & x_{i n} \\
\cdot & \cdot & \cdot & \cdot & \cdot & \cdot \\
x_{m 1} & x_{m 2} & \cdot & x_{m j} & \cdot & x_{m n}
\end{array}\right]
$$

Yöntemin çözüm adımları aşağıda özetlenmektedir (Hwang ve Yoon 1981):

Adım 1: Normalize edilmiş karar matrisinin oluşturulması. $\mathrm{Bu}$ işlemin amacı kriterlerin farklı ölçüm birimlere sahip değerlerinin karşılaştırma olanağı sağlamak için birim olamayan bir ortama dönüştürülmesidir. Normalizasyon işlemi için $r_{i j}=$ $\frac{x_{i j}}{\sqrt{\sum_{i=1}^{m} x_{i j}{ }^{2}}}$ eşitliği kullanılmaktadır.

Adım 2: Normalize edilmiş ağırlıklı karar matrisinin oluşturulması. Ağırlıkların toplamı 1 değerini alacak şekilde $w_{1}, w_{2}, \ldots, w_{n}$ olarak tanımlanmış $\mathrm{n}$ adet ağırlık belirlenmiş olsun. Normalize edilmiş ağırlıklı karar matrisi elde etmek için 
normalize edilmiş karar matrisi bu ağırlıklarla çarpılır. Normalize edilmiş ağırlıklı karar matrisi $V_{m n}$ olarak gösterilmektedir. Bu çalışmada AHP yönteminden elde edilen ağırlıklar TOPSIS yönteminde ağırlıklı karar matrisinin oluşturulmasında kullanılacaktır.

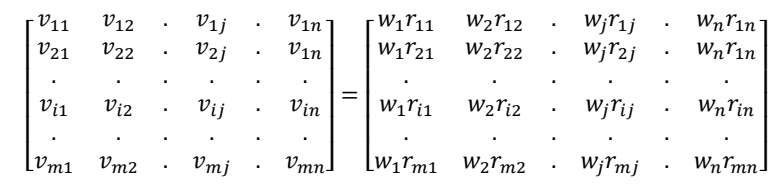

Adım 3: İdeal çözüm ve ideal çözümden en uzak çözümü belirleme. İdeal çözüm için $\mathrm{A}^{+}$ve $\mathrm{A}^{-}$vektörleri aşağıdaki eşitlikler kullanılarak oluşturulur. Buradaki amaç en iyi olabilecek alternatifi ve en istenmeyen alternatifi tanımlamaktır.

$$
\begin{aligned}
& A^{+}=\left\{v_{1}^{+}, \ldots, v_{n}^{+}\right\}=\left\{\left(\max _{i} v_{i j} \mid i \in I\right),\left(\min _{i} v_{i j} \mid i \in I^{\prime}\right)\right\} \\
& A^{-}=\left\{v_{1}^{-}, \ldots, v_{n}^{-}\right\}=\left\{\left(\min _{i} v_{i j} \mid i \in I^{\prime}\right),\left(\max _{i} v_{i j} \mid i \in I^{\prime}\right)\right\}
\end{aligned}
$$$$
\text { (I: fayda ölçütleri), (I': maliyet ölçütleri) }
$$

Adım 4: Ayırım yapmak için ölçüleri hesaplama. Her alternatifin ideal çözümden uzaklığ $\left(S_{i}^{+}\right)$ve ideal çözümden en uzak çözüme olan uzaklığı $\left(S_{i}^{-}\right)$hesaplanır.

$$
S_{i}^{+}=\sqrt{\left(\sum_{j=1}^{n}\left(v_{i j}-v_{j}^{+}\right)^{2}\right)}, S_{i}^{-}=\sqrt{\left(\sum_{j=1}^{n}\left(v_{i j}-v_{j}^{-}\right)^{2}\right)}
$$

Adım 5: İdeal çözüme göreceli uzaklığı hesaplama. Her alternatifin $A^{+}$vektörüne göre göreceli uzaklığı,

$$
C_{i}^{+}=\frac{S_{i}^{-}}{S_{i}^{+}+S_{i}^{-}}, 0<C_{i}^{+}<1
$$

formülü kullanılarak hesaplanmaktadır.

Adım 6: Alternatifleri sıralama. $C_{i}^{+}$değerleri kullanılarak tüm alternatifler büyükten küçüğe doğru sıralanır. En büyük değer en iyi sonucu gösterir.

\section{Bulgular}

Çalışmada ele alınan ve gübre üretimi ve pazarlaması yapan işletmenin hedef pazar yeri seçimi için kriterler firma yöneticileri tarafindan nüfus, KGSMH, gübre tüketimi, gübre üretimi, gübre ticareti dengesi, iş yapma kolaylığı, ülkelere uzaklık ve lojistik performans şeklinde belirlenmişti. Kriterlerin diğer kriterlere göre önem derecelerini belirlemede AHP yönteminden faydalanılmıştır. Bunun için Çizelge 3'de verilen form kriterlerin karşılaştırılmasının yapılması için, uygulama yapılan firmanın yöneticileri tarafindan toplantı ortamında ortak kararla doldurulmuştur.

Yukarıdaki değerlendirmeler ikili karşılaştırma matrisi şekline dönüştürülerek Çizelge 4'de verilmiştir.

$\mathrm{Bu}$ çizelgede verilen değerler normalize edilerek satır ortalamaları alınmış ve ağırlıklar hesaplanmıștır. Matris için tutarlık oranı 0.099 bulunmuştur. Bu değer 0.10'dan küçük olduğundan değerlendirmelerin tutarlı olduğu kanaatine varılmıştır. AHP kullanılarak bulunan kriter ağırlıkları Çizelge 5'de görülmektedir.
Çizelge 5 dikkate alınarak önem dereceleri değerlendirildiğinde işletme için en önemli kriterin en yüksek ağırlığa sahip olan "ülkelere uzaklık kriteri" olduğu ve bunu "ticaret dengesi" kriterinin takip ettiği örülmektedir. Ele alınan işletme için Ülkelere Uzaklık \%39, Ticaret Dengesi \%25, Kişi başı GSMH \%16, Nüfus \%6, Gübre Tüketimi \%4, Gübre Üretimi \%4, İş Yapma Kolaylığı \%3, Lojistik Performans \%3 öneme sahiptir.

İşletme için hedef pazar olabilecek ülkelerin ele alınan kriterler açısından sıralanması TOPSIS yöntemi kullanılarak elde edilmiştir. Yöntemin uygulanması için Çizelge 6'da oluşturulan veri seti kullanılmıştır.

$\mathrm{Bu}$ verilerden faydalanarak önce normalize edilmiş karar matrisi oluşturulmuștur. Normalize edilmiş ağırlıklı karar matrisini elde etmek için normalize edilmiş karar matrisi ile AHP yönteminden elde edilen kriter ağırlıkları çarpılmıştır.

İdeal çözüm için $\mathrm{A}^{+}$vektörü ve istenmeyen çözüm için $\mathrm{A}^{-}$ vektörü aşağıdaki şekilde oluşturulmuştur.

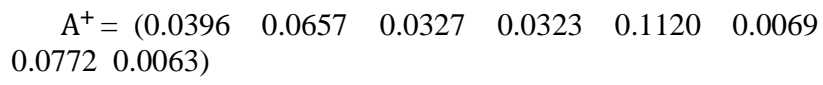

$$
\mathrm{A}^{-}=\left(\begin{array}{llllll}
0.0001 & 0.0006 & 0.0000 & 0.0000 & -0.1335 & 0.0001
\end{array}\right.
$$$$
0.00000 .0032)
$$

Her alternatifin ideal çözümden uzaklığı $\left(\mathrm{S}_{\mathrm{i}}^{+}\right)$ve ideal çözümden en uzak çözüme olan uzaklığı $\left(S_{\mathrm{i}}^{-}\right)$hesaplanmıştır. Daha sonra her alternatifin $\mathrm{A}^{+}$vektörüne göre göreceli uzaklığ 1 $\mathrm{C}_{\mathrm{i}}^{+}$bulunmuştur. Sıralanan alternatifler arasından ilk 10 sırada yer alan ve hedef pazar olabilecek ülkeler Çizelge 7'de verilmiştir.

\section{Sonuç}

Hedef pazar yeri seçimi sektörden sektöre veya işletmeden işletmeye değişebilecek önemli bir problemdir. Sadece geçmiş yıllardaki tecrübelere göre veya yöneticilerin sezgilerine göre değil birtakım veriler üzerinden nicel teknikler kullanılarak değerlendirilmesi oldukça önemlidir. Bu çalışmada Antalya'da faaliyet gösteren bir gübre üreticisinin hedef pazar yeri seçimi ele alınmıştır. Hedef pazar belirleme ile ilgili ele alınan kriterler kendi aralarında değerlendirilerek ilgili gübre üreticisi için önemli olan kriterler belirlenmiştir. Belirlenen kriterlerin hangilerinin ne kadar öneme sahip oldukları AHP Yöntemi ile belirlenmiştir. İşletme için uzaklık kriterinin hedef pazar yeri seçiminde en önemli kriter olduğu ve bu kriteri ticaret dengesi kriterinin takip ettiği görülmüştür. AHP yönteminden elde edilen ağırlıklar ülke seçiminde TOPSIS yöntemine girdi olarak kullanılmıştır. İşletmenin 10 faaliyet için bütçe ayırdığını dikkate alarak hedef pazar olarak bütünleşik AHP-TOPSIS yöntemi ile elde edilen siralamaya göre ilk 10 ülke belirlenmiştir. $\mathrm{Bu}$ ülkeler Hindistan, Brezilya, ABD, Tayland, İngiltere, İsveç, Endonezya, İspanya, Japonya, Bangladeş’tir.

Yapılan çalışma tüm gübre çeşitlerini ele aldığı için hedef pazar seçimi için genel bir fikir vermektedir. Sektörde tek türde gübre olmadığı gibi talep eden ülkelerde ihtiyaç duyulan miktarlar (kullanılan ürün çeşitliliğine ve ihtiyacına göre) farklılık gösterecektir. Dolayısıyla ilerleyen çalışmalarda ürün ayrımı mikro seviyede yapılarak işletme için çeşitli sonuçlar elde edilebilir. İşletmenin pazarlamak istediği ürünler analiz edilerek her ürün için farklı alternatif sayılarıyla tekrar analizler yapılabileceği gibi farklı çok kriterli karar verme yöntemleriyle işletmelere karar desteği sağlanabileceği görülmektedir. 
Çizelge 3. Kriterlerin karşılaştırılması.

Table 3. Comparison of criteria.

\begin{tabular}{|c|c|c|c|c|c|c|c|c|c|c|c|c|c|c|c|c|c|c|}
\hline & 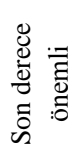 & 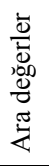 & $\begin{array}{l}: \bar{E} \\
\overline{0} \\
: 0 \\
\ddot{0} \\
0 .\end{array}$ & 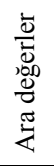 & 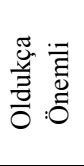 & 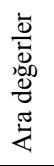 & 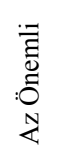 & 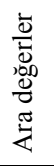 & : t: & 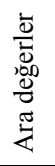 & 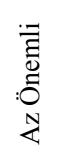 & 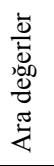 & 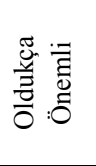 & 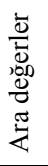 & $\begin{array}{l}: \bar{E} \\
\bar{\Xi} \\
: 0 \\
\ddot{y} \\
\dot{0}\end{array}$ & 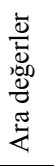 & 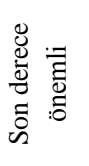 & \\
\hline Nüfus & 9 & 8 & 7 & 6 & 5 & 4 & 3 & 2 & 1 & 2 & 3 & 4 & 5 & 6 & 7 & 8 & 9 & KGSMH \\
\hline Nüfus & 9 & 8 & 7 & 6 & 5 & 4 & 3 & 2 & 1 & 2 & 3 & 4 & 5 & 6 & 7 & 8 & 9 & Gübre Tüketimi \\
\hline Nüfus & 9 & 8 & 7 & 6 & 5 & 4 & 3 & 2 & 1 & 2 & 3 & 4 & 5 & 6 & 7 & 8 & 9 & Gübre Üretimi \\
\hline Nüfus & 9 & 8 & 7 & 6 & 5 & 4 & 3 & 2 & 1 & 2 & 3 & 4 & 5 & 6 & 7 & 8 & 9 & Ticaret Dengesi \\
\hline Nüfus & 9 & 8 & 7 & 6 & 5 & 4 & 3 & 2 & 1 & 2 & 3 & 4 & 5 & 6 & 7 & 8 & 9 & $\begin{array}{l}\text { İş Yapma } \\
\text { Kolaylığı }\end{array}$ \\
\hline Nüfus & 9 & 8 & 7 & 6 & 5 & 4 & 3 & 2 & 1 & 2 & 3 & 4 & 5 & 6 & 7 & 8 & 9 & Ülkelere Uzaklık \\
\hline Nüfus & 9 & 8 & 7 & 6 & 5 & 4 & 3 & 2 & 1 & 2 & 3 & 4 & 5 & 6 & 7 & 8 & 9 & $\begin{array}{c}\text { Lojistik } \\
\text { Performans }\end{array}$ \\
\hline KGSMH & 9 & 8 & 7 & 6 & 5 & 4 & 3 & 2 & 1 & 2 & 3 & 4 & 5 & 6 & 7 & 8 & 9 & Gübre Tüketimi \\
\hline KGSMH & 9 & 8 & 7 & 6 & 5 & 4 & 3 & 2 & 1 & 2 & 3 & 4 & 5 & 6 & 7 & 8 & 9 & Gübre Üretimi \\
\hline KGSMH & 9 & 8 & 7 & 6 & 5 & 4 & 3 & 2 & 1 & 2 & 3 & 4 & 5 & 6 & 7 & 8 & 9 & Ticaret Dengesi \\
\hline KGSMH & 9 & 8 & 7 & 6 & 5 & 4 & 3 & 2 & 1 & 2 & 3 & 4 & 5 & 6 & 7 & 8 & 9 & $\begin{array}{l}\text { İş Yapma } \\
\text { Kolaylığı }\end{array}$ \\
\hline KGSMH & 9 & 8 & 7 & 6 & 5 & 4 & 3 & 2 & 1 & 2 & 3 & 4 & 5 & 6 & 7 & 8 & 9 & Ülkelere Uzaklık \\
\hline KGSMH & 9 & 8 & 7 & 6 & 5 & 4 & 3 & 2 & 1 & 2 & 3 & 4 & 5 & 6 & 7 & 8 & 9 & $\begin{array}{l}\text { Lojistik } \\
\text { Performans }\end{array}$ \\
\hline $\begin{array}{l}\text { Gübre } \\
\text { Tüketimi }\end{array}$ & 9 & 8 & 7 & 6 & 5 & 4 & 3 & 2 & 1 & 2 & 3 & 4 & 5 & 6 & 7 & 8 & 9 & Gübre Üretimi \\
\hline $\begin{array}{l}\text { Gübre } \\
\text { Tüketimi }\end{array}$ & 9 & 8 & 7 & 6 & 5 & 4 & 3 & 2 & 1 & 2 & 3 & 4 & 5 & 6 & 7 & 8 & 9 & Ticaret Dengesi \\
\hline $\begin{array}{l}\text { Gübre } \\
\text { Tüketimi }\end{array}$ & 9 & 8 & 7 & 6 & 5 & 4 & 3 & 2 & 1 & 2 & 3 & 4 & 5 & 6 & 7 & 8 & 9 & $\begin{array}{l}\text { İş Yapma } \\
\text { Kolaylığ }\end{array}$ \\
\hline $\begin{array}{l}\text { Gübre } \\
\text { Tüketimi }\end{array}$ & 9 & 8 & 7 & 6 & 5 & 4 & 3 & 2 & 1 & 2 & 3 & 4 & 5 & 6 & 7 & 8 & 9 & Ülkelere Uzaklık \\
\hline $\begin{array}{l}\text { Gübre } \\
\text { Tüketimi }\end{array}$ & 9 & 8 & 7 & 6 & 5 & 4 & 3 & 2 & 1 & 2 & 3 & 4 & 5 & 6 & 7 & 8 & 9 & $\begin{array}{c}\text { Lojistik } \\
\text { Performans }\end{array}$ \\
\hline $\begin{array}{l}\text { Gübre } \\
\text { Üretimi }\end{array}$ & 9 & 8 & 7 & 6 & 5 & 4 & 3 & 2 & 1 & 2 & 3 & 4 & 5 & 6 & 7 & 8 & 9 & Ticaret Dengesi \\
\hline $\begin{array}{l}\text { Gübre } \\
\text { Üretimi }\end{array}$ & 9 & 8 & 7 & 6 & 5 & 4 & 3 & 2 & 1 & 2 & 3 & 4 & 5 & 6 & 7 & 8 & 9 & $\begin{array}{l}\text { İş Yapma } \\
\text { Kolaylığ } 1\end{array}$ \\
\hline $\begin{array}{c}\text { Gübre } \\
\text { Üretimi }\end{array}$ & 9 & 8 & 7 & 6 & 5 & 4 & 3 & 2 & 1 & 2 & 3 & 4 & 5 & 6 & 7 & 8 & 9 & Ülkelere Uzaklık \\
\hline $\begin{array}{l}\text { Gübre } \\
\text { Üretimi }\end{array}$ & 9 & 8 & 7 & 6 & 5 & 4 & 3 & 2 & 1 & 2 & 3 & 4 & 5 & 6 & 7 & 8 & 9 & $\begin{array}{c}\text { Lojistik } \\
\text { Performans }\end{array}$ \\
\hline $\begin{array}{l}\text { Ticaret } \\
\text { Dengesi }\end{array}$ & 9 & 8 & 7 & 6 & 5 & 4 & 3 & 2 & 1 & 2 & 3 & 4 & 5 & 6 & 7 & 8 & 9 & $\begin{array}{l}\text { İş Yapma } \\
\text { Kolaylığ } 1\end{array}$ \\
\hline $\begin{array}{l}\text { Ticaret } \\
\text { Dengesi }\end{array}$ & 9 & 8 & 7 & 6 & 5 & 4 & 3 & 2 & 1 & 2 & 3 & 4 & 5 & 6 & 7 & 8 & 9 & Ülkelere Uzaklık \\
\hline $\begin{array}{c}\text { Ticaret } \\
\text { Dengesi }\end{array}$ & 9 & 8 & 7 & 6 & 5 & 4 & 3 & 2 & 1 & 2 & 3 & 4 & 5 & 6 & 7 & 8 & 9 & $\begin{array}{l}\text { Lojistik } \\
\text { Performans }\end{array}$ \\
\hline $\begin{array}{l}\text { İş Yapma } \\
\text { Kolaylığ }\end{array}$ & 9 & 8 & 7 & 6 & 5 & 4 & 3 & 2 & 1 & 2 & 3 & 4 & 5 & 6 & 7 & 8 & 9 & Ülkelere Uzaklık \\
\hline $\begin{array}{l}\text { İş Yapma } \\
\text { Kolaylığı }\end{array}$ & 9 & 8 & 7 & 6 & 5 & 4 & 3 & 2 & 1 & 2 & 3 & 4 & 5 & 6 & 7 & 8 & 9 & $\begin{array}{c}\text { Lojistik } \\
\text { Performans }\end{array}$ \\
\hline $\begin{array}{l}\text { Ülkelere } \\
\text { Uzaklık }\end{array}$ & 9 & 8 & 7 & 6 & 5 & 4 & 3 & 2 & 1 & 2 & 3 & 4 & 5 & 6 & 7 & 8 & 9 & $\begin{array}{c}\text { Lojistik } \\
\text { Performans }\end{array}$ \\
\hline
\end{tabular}

Çizelge 4. Kriterlerin ikili karşılaştırma matrisi.

Table 4. Pairwise comparision matrix of criteria.

\begin{tabular}{ccccccccc}
\hline Kriterler & Nüfus & KGSMH & $\begin{array}{c}\text { Gübre } \\
\text { Tüketimi }\end{array}$ & $\begin{array}{c}\text { Gübre } \\
\text { Urretimi }\end{array}$ & $\begin{array}{c}\text { Ticaret } \\
\text { Dengesi }\end{array}$ & $\begin{array}{c}\text { İş Yapma } \\
\text { Kolayllğ } 1\end{array}$ & $\begin{array}{c}\text { Ülkelere } \\
\text { Uzaklık }\end{array}$ & $\begin{array}{c}\text { Lojistik } \\
\text { Performans }\end{array}$ \\
\hline Nüfus & 1 & $1 / 5$ & 1 & 1 & $1 / 5$ & 3 & $1 / 7$ & 3 \\
KGSMH & 5 & 1 & 7 & 3 & $1 / 5$ & 5 & $1 / 5$ & 7 \\
Gübre Tüketimi & 1 & $1 / 7$ & 1 & 1 & $1 / 9$ & 1 & $1 / 9$ & 1 \\
Gübre Üretimi & 1 & $1 / 3$ & 1 & 1 & $1 / 7$ & 1 & $1 / 9$ & 1 \\
Ticaret Dengesi & 5 & 5 & 9 & 7 & 1 & 7 & $1 / 3$ & 5 \\
İş Yapma Kolaylığ & $1 / 3$ & $1 / 5$ & 1 & 1 & $1 / 7$ & 1 & $1 / 9$ & 1 \\
Ülkelere Uzaklı & 7 & 5 & 9 & 9 & 3 & 9 & 1 & 9 \\
Lojistik Performans & $1 / 3$ & $1 / 7$ & 1 & 1 & $1 / 5$ & 1 & $1 / 9$ & 1 \\
\hline
\end{tabular}


Çizelge 5. Kriter ağırlıkları.

Table 5. Weights of criteria.

\begin{tabular}{cc}
\hline Kriterler & A ğırlıklar \\
\hline Nüfus & 0.058 \\
KGSMH & 0.156 \\
Gübre Tüketimi & 0.035 \\
Gübre Üretimi & 0.038 \\
Ticaret Dengesi & 0.254 \\
İş Yapma Kolaylığı & 0.033 \\
Ülkelere Uzaklık & 0.393 \\
Lojistik Performans & 0.033 \\
\hline
\end{tabular}

Çizelge 6. TOPSIS Yöntemi için Kullanılan Veri Seti.

Table 6. Data set used for TOPSIS method.

\begin{tabular}{|c|c|c|c|c|c|c|c|c|}
\hline Ülkeler & $\begin{array}{c}\text { Nüfus } \\
\text { (milyon) }\end{array}$ & $\begin{array}{c}\text { KGSMH } \\
(\$)\end{array}$ & $\begin{array}{c}\text { Gübre üretimi } \\
\text { (Tüketime göre \%) }\end{array}$ & $\begin{array}{c}\text { Gübre tüketim } \\
\text { endeksi } \\
\text { (en yüksek en } \\
\text { iyi) }\end{array}$ & $\begin{array}{c}\text { Ticaret } \\
\text { dengesi } \\
(\mathbf{x} 1000 \$)\end{array}$ & $\begin{array}{c}\text { İş yapma } \\
\text { kolaylığı } \\
\text { (en küçük değer } \\
\text { en iyi) }\end{array}$ & $\begin{array}{c}\text { Ülkelere } \\
\text { uzaklık } \\
\text { (en uzak 0 } \\
\text { değeri alır) }\end{array}$ & $\begin{array}{c}\text { Lojistik } \\
\text { performans } \\
\text { (1= düşük, } \\
5=\text { yüksek) }\end{array}$ \\
\hline $\mathrm{ABD}$ & 321.4 & 52061 & 95 & 21257 & 3963458 & 182 & 3529 & 4.0 \\
\hline Almanya & 81.4 & 46402 & 86 & 2411 & -1162051 & 173 & 11356 & 4.2 \\
\hline Azerbaycan & 9.7 & 6116 & 0 & 33 & 67287 & 125 & 12646 & 3.0 \\
\hline BAE & 9.2 & 39340 & 3 & 32 & -640917 & 164 & 11247 & 3.9 \\
\hline Bangladeş & 161.0 & 1035 & 469 & 1950 & 1040887 & 14 & 8295 & 2.7 \\
\hline Brezilya & 207.8 & 10917 & 441 & 13301 & 6315402 & 67 & 2954 & 3.1 \\
\hline Bulgaristan & 7.2 & 7455 & 115 & 473 & 45627 & 151 & 12790 & 2.8 \\
\hline Cezayir & 39.7 & 4794 & 59 & 120 & -194758 & 34 & 10391 & 2.8 \\
\hline Çin & 1371.2 & 6470 & 88 & 58886 & -6949605 & 112 & 7761 & 3.7 \\
\hline Endonezya & 257.6 & 3710 & 116 & 4724 & 1708039 & 99 & 4624 & 3.0 \\
\hline Etiyopya & 99.4 & 619 & 0 & 287 & 424017 & 31 & 10354 & 2.4 \\
\hline Fas & 34.4 & 3179 & 19 & 515 & -1616413 & 122 & 9827 & 2.7 \\
\hline Gana & 27.4 & 1645 & 0 & 118 & 113021 & 82 & 8714 & 2.7 \\
\hline Güney Afrika & 55.0 & 7402 & 518 & 713 & 71568 & 116 & 5876 & 3.8 \\
\hline Gürcistan & 3.7 & 4010 & 33 & 74 & -92234 & 174 & 12932 & 2.4 \\
\hline Hindistan & 1311.1 & 1730 & 157 & 24649 & 7362582 & 60 & 9080 & 3.4 \\
\hline Irak & 36.4 & 4696 & 113 & 215 & 80555 & 25 & 12721 & 2.1 \\
\hline İngiltere & 65.1 & 40362 & 243 & 1541 & 734139 & 183 & 10329 & 4.1 \\
\hline İran & 79.1 & 17140 & 78 & 491 & -579268 & 70 & 11898 & 2.6 \\
\hline İspanya & 46.4 & 30569 & 117 & 1747 & 392371 & 158 & 10402 & 3.7 \\
\hline İsveç & 9.8 & 56449 & 0 & 218 & 153332 & 181 & 11088 & 4.2 \\
\hline Japonya & 127.0 & 46490 & 133 & 1072 & 701286 & 156 & 5183 & 4.0 \\
\hline Kanada & 35.9 & 49685 & 30 & 4041 & -4772800 & 168 & 4873 & 3.9 \\
\hline Katar & 2.2 & 72334 & 6 & 97 & -1746967 & 107 & 11586 & 3.6 \\
\hline Kazakistan & 17.5 & 10046 & 141 & 59 & 22589 & 155 & 10988 & 2.8 \\
\hline Kenya & 46.1 & 1125 & 0 & 302 & 85107 & 98 & 9367 & 3.3 \\
\hline Kolombiya & 48.2 & 7309 & 310 & 1090 & 650858 & 137 & 2361 & 2.6 \\
\hline Güney Kore & 50.6 & 25140 & 80 & 540 & 243220 & 185 & 5921 & 3.7 \\
\hline Kuveyt & 3.9 & 39353 & 1 & 3 & -251453 & 88 & 12158 & 3.2 \\
\hline Libya & 6.3 & 15775 & 13 & 7 & -73341 & 2 & 11524 & 2.3 \\
\hline Malezya & 30.3 & 10576 & 299 & 1645 & 667654 & 167 & 5998 & 3.4 \\
\hline Meksika & 127.0 & 9443 & 193 & 1792 & 1021529 & 143 & 1925 & 3.1 \\
\hline Misir & 91.5 & 2656 & 70 & 1681 & -242929 & 68 & 12299 & 3.2 \\
\hline Nijerya & 182.2 & 2479 & 304 & 544 & 76848 & 21 & 9465 & 2.6 \\
\hline Peru & 31.4 & 5724 & 0 & 436 & 550835 & 136 & 1315 & 2.9 \\
\hline Polonya & 38.0 & 14132 & 115 & 1932 & 69847 & 166 & 11808 & 3.4 \\
\hline Romanya & 19.8 & 9288 & 80 & 490 & 303999 & 154 & 12567 & 3.0 \\
\hline Rusya & 144.1 & 10740 & 10 & 1834 & -8778439 & 150 & 8460 & 2.6 \\
\hline S.Arabistan & 31.5 & 21746 & 22 & 899 & -943135 & 96 & 11795 & 3.2 \\
\hline Singapur & 5.5 & 49467 & 0 & 2 & -11213 & 188 & 5636 & 4.1 \\
\hline Şili & 17.9 & 14355 & 36 & 560 & -254278 & 133 & 0 & 3.2 \\
\hline Tanzanya & 53.5 & 828 & 0 & 54 & 154455 & 58 & 8670 & 3.0 \\
\hline Tayland & 68.0 & 5474 & 2844 & 2807 & 1635178 & 144 & 6887 & 3.3 \\
\hline Türkmenistan & 5.4 & 6933 & 0 & 0 & -12225 & 190 & 11615 & 2.2 \\
\hline Ukrayna & 45.2 & 2786 & 93 & 1464 & 174268 & 110 & 12614 & 2.7 \\
\hline Umman & 4.5 & 15470 & 1 & 34 & -657151 & 124 & 10947 & 3.2 \\
\hline Ürdün & 7.6 & 3926 & 5 & 157 & -779860 & 72 & 12775 & 3.0 \\
\hline Vietnam & 91.7 & 1593 & 197 & 2827 & 1159357 & 108 & 6138 & 3.0 \\
\hline
\end{tabular}


Çizelge 7. TOPSIS yöntemiyle hedef pazar seçimi sıralama sonucu. Table 7. Target market selection by TOPSIS method ranking results.

\begin{tabular}{cc}
\hline Ülke Adı & Sıralama \\
\hline Hindistan & 0.767 \\
Brezilya & 0.704 \\
ABD & 0.686 \\
Tayland & 0.577 \\
İngiltere & 0.573 \\
İsveç & 0.558 \\
Endonezya & 0.557 \\
İspanya & 0.548 \\
Japonya & 0.546 \\
Bangladeş & 0.546 \\
\hline
\end{tabular}

\section{Kaynaklar}

Bhushan N, Rai K (2007) Strategic decision making: applying the Analytic Hierarchy Process. Springer Science \& Business Media.

Cuyvers L, De Pelsmacker P, Rayp G, Roozen IT (1995) A decision support model for the planning and assessment of export promotion activities by government export promotion institutions - the Belgian case. International Journal of Research in Marketing 12(2): 173-186.

Çakır S, Perçin S (2013) Çok kriterli karar verme teknikleriyle lojistik firmalarinda performans ölçümü. Ege Akademik Bakış 13(4): 449.

Distance From To (2015) Distance between countries. http://www.distancefromto.net/countries.php Erişim 25 Aralık 2015.

Górecka D, Szałucka M (2013) Country Market selection in international expansion using multicriteria decision aiding methods. Multiple Criteria Decision Making (8): 32-55.

Gould RR (2002) International market selection-screening technique. Australia: RMIT University Faculty of Constructed Environment a Doctoral Dissertation.

Holzmüller HH, Kasper H (1990) The decision-maker and export activity: a cross-national comparison of the foreign orientation of Austrian managers. Management International Review 30(3): 217 230.

Hwang CL, Yoon K (1981) Multiple Attributes decision making methods and applications. Berlin: Springer.

Malhotra S, Sivakumar K, Zhu P (2009) Distance factors and target market selection: the moderating effect of market potential. International Marketing Review 26(6): 651-673.

Miečinskienė A, Stasytytė V, Kazlauskaitė J (2014) Reasoning of export market selection. Procedia-Social and Behavioral Science 110: 1166-1175.

Özyörük B, Özcan E (2005) Otomotiv sektöründe tedarikçi seçimine etki eden faktörler ve tedarikçi seçimi. V. Ulusal Üretim Araştırmaları Sempozyumu 625-629.
Rahman SH (2003) Modelling of international market selection process: a qualitative study of successful Australian international businesses. Qualitative Market Research: An International Journal 6(2): 119. 132.

Robertson KR, Wood VR (2001) The relative importance of types of information in the foreign market selection process. International Business Review 10(3): 363-379.

Saaty T, Vargas L (2001) Models, methods, concepts and applications of the Analytic Hierarchy Process. New York: Springer.

Sakarya S, Eckman M, Hyllegard KH (2007) Market selection for international expansion: assessing opportunities in emerging markets. International Marketing Review 24(2): 208-238.

Şener HY (2014) Determining new markets using Analytic Hierarchy Process: case study in Güral Porcelain. International Journal of Marketing Studies 6(5): 149.

Simkin L, Dibb S (1998) Prioritising target markets. Marketing Intelligence \& Planning 16(7): 407-417.

Soner S, Önüt S (2006) Multi-Criteria supplier selection: an ELECTREAHP application. Sigma 4: 110-120.

Söyler H, Yaraş E (2016) Küresel pazara giriș kararının bulanık AHP ve bulanık TOPSIS yaklaşımıyla analizi. Manas Sosyal Araştırmalar Dergisi 5(4): 77-96.

Steenkamp E, Rossouw R, Viviers W, Cuyvers L (2009) Export market selection methods and the 1dentification of realistic export opportunities for South Africa using a decision support model. Trade and Industrial Policy Strategies Working Paper Series 3: 134

Ticaret Bakanlığı (2015) Hedef ve öncelikli ülkeler. https://www.ticaret.gov.tr/ihracat/pazara-giris/hedef-ve-oncelikliulkeler. Erişim 15 Aralık 2015.

Toksarı M, Toksarı MD (2011) Bulanık Analitik Hiyerarsi Prosesi (AHP) yaklaşımı kullanılarak hedef pazarın belirlenmesi. METU Studies in Development 38(1): 51.

Trademap (2015) Trade statistics for international business development. http://www.trademap.org/Index.aspx. Erişim 31 Aralik 2015.

Uygurtürk H, Korkmaz T (2012) Finansal performansın TOPSIS çok kriterli karar verme yöntemi ile belirlenmesi: ana metal sanayi işletmeleri üzerine bir uygulama. Eskişehir Osmangazi Üniversitesi İktisadi ve İdari Bilimler Dergisi 7(2): 95-115.

Vargas L, Saaty T (1982) The logic of priorities. USA: Springer.

World Bank Group (2015) Indicators database. http://data.worldbank.org/indicator/ Erişim 21 Aralık 2015.

Yavuz V (2016) Coğrafi pazar seçiminde Promethee ve Entropi yöntemlerine dayalı çok kriterli bir analiz: mobilya sektöründe bir uygulama. Niğde Üniversitesi İktisadi ve İdari Bilimler Fakültesi Dergisi 9(2): 163-177.

Yılmaz K, Öztürk Y, Burdurlu E (2017) Çok ölçütlü karar verme yaklaşımı ile mobilya işletmeleri için hedef pazar seçimi. İleri Teknoloji Bilimleri Dergisi 6(3): 744-756. 